\title{
Slope stability analysis in Ulubelu Lampung using computational analysis program
}

\author{
Jafri $M^{1}$, Iswan ${ }^{1}$, Rizki $M^{1}$, and Susilo G.E ${ }^{1}$ \\ ${ }^{1}$ Civil Engineering Department, Universitas Lampung, 35145, Indonesia \\ jafri@unila.ac.id
}

Received 02-03-2020; accepted 27-03-2020

\begin{abstract}
Ulubelu sub-district is the center of geothermal activity in Lampung Province. The Ulubelu geothermal project supply $25 \%$ of electricity to Lampung Province. In the future the Government plans to build a geothermal pipeline network with the aim of maximizing the potential found in Ulubelu. One of the objects that must be examined in the construction of the pipeline is the stability of the slope that will be passed by geothermal pipes. Therefore, this study aims to analyze the stability of landslides in the Ulubelu geothermal pipeline. Soil samples for this study were taken from 5 locations: BH-01, BH-02, BH-03, BH-04, and BH-05. This soil sample is then examined to determine its soil mechanics characteristics in the laboratory. The safety factor of each sample is analyzed using 3 slope analysis methods: the Fellenius method, the Bishop method, and the Janbu method, and calculated in Geostudio (Slope/W). The results showed that all samples showed safety factor values that were not much different that were spread between the numbers 1.7 to 4.3. This shows that all sample locations are safe from landslides. This also shows that the characteristics of the soil and the slope of the study area are almost the same.
\end{abstract}

Keywords: Slope, safety factor, Fellenius, Bishop, Janbu, Geostudio(Slope/W)

\section{Introduction}

Tanggamus is one of the areas in Lampung that has a large geothermal potential. The Lampung Provincial Government claims the province has a geothermal potential of $2,867 \mathrm{MW}$ or $10 \%$ of Indonesia's total geothermal potential. With this potential, the province is ranked third after West Java and North Sumatra as the province with the largest geothermal potential in the country. Overall, the government said Indonesia's geothermal energy potential was 29,000 MW. The International Geothermal Association (IGA) states that Indonesia has the third largest installed capacity after the US and the Philippines, with a capacity of 1,340 MW as of 2015. Meanwhile, the US and the Philippines have an installed capacity of 3,450 MW and 1,870 MW, respectively. Ulubelu sub-district is the center of geothermal activity in Tanggamus. It is located in the hills with a distance of about 3-4 hours by road from Bandar Lampung, the capital of Lampung Province. To reach the location, we must pass ravines, cliffs and forests. There is the Ulubelu Geothermal Power Plant (PLTP) owned by PT

Cites this as: Jafri, M., Iswan, Rizki, M., \& Susilo, G.E. (2000). Slope stability analysis in Ulubelu Lampung using computational analysis program. Civil and Environmental Science Journal, 3(1), pp.51-59. doi: https://doi.org/10.21776/ub.civense.2020.00301.6 
Pertamina Geothermal Energy (PGE) which has four electricity generating units. PGE is a subsidiary of PT Pertamina (Persero) which focuses on geothermal development.

Geothermal development in the Ulubelu region has actually been carried out since 1991. However, the monetary crisis that occurred 20 years ago made the project halted. PGE only started to develop again in 2008. Ulubelu PLTP is not the only power plant that uses renewable energy. The development and opening of new wells continue at Ulu Belu to meet the supply of fuel to power plants. The contribution of $25 \%$ of electricity supply to Lampung Province is the main advantage of the utilization of Ulubelu geothermal energy [1].

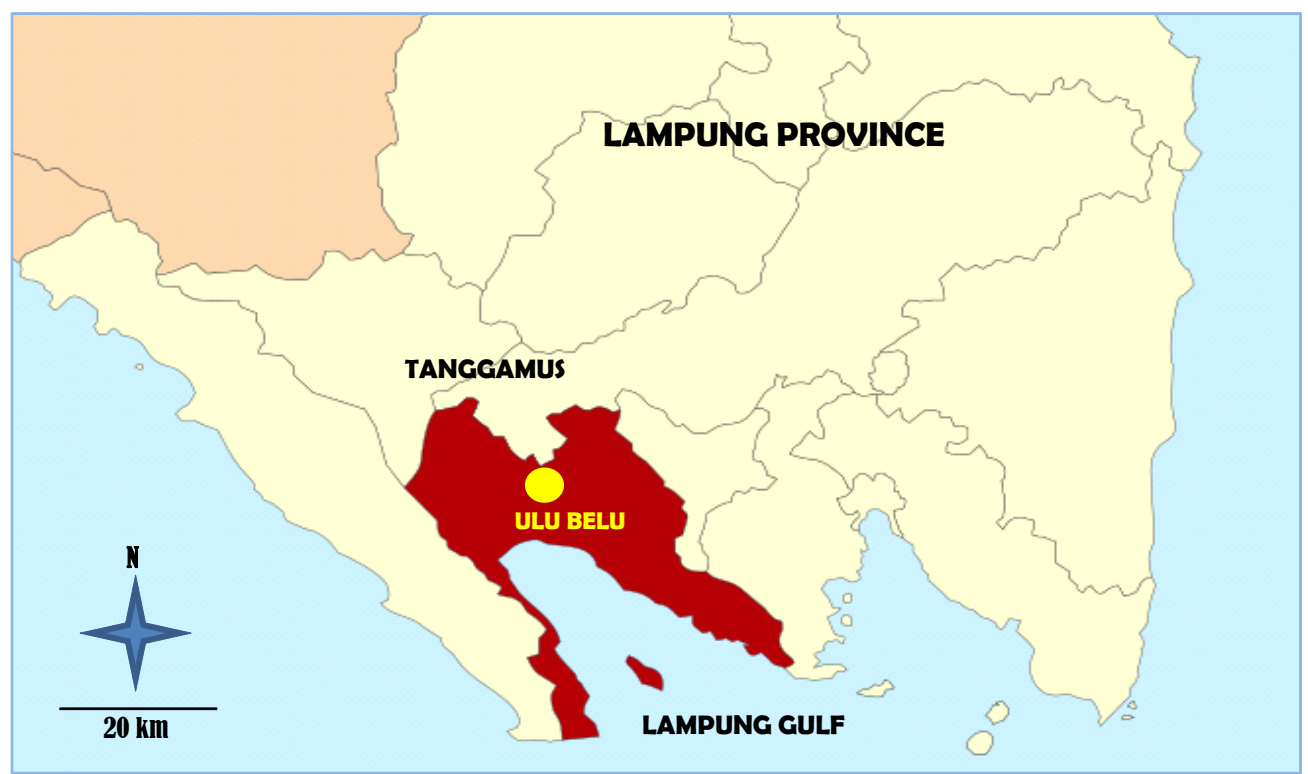

Figure 1. Map of Tanggamus District and the location of Ulu Belu

In the future the Government plans to build a geothermal pipeline network with the aim of maximizing the potential found in Ulubelu. To build a geothermal pipe that can last a long time, it is necessary to calculate the soil safety factor so that the foundation of the geothermal pipe is resistant to the load that will be placed on it. Therefore, this study intends to analyze the safety factor of the slope stability at places that will be crossed by geothermal pipelines.

\section{Material and Methods}

\subsection{Soil Sampling}

Soil samples were taken from five different points in Ulubelu. Furthermore, the locations of the sampling points are named $\mathrm{BH}-01, \mathrm{BH}-02, \mathrm{BH}-03, \mathrm{BH}-04$, and $\mathrm{BH}-05$. $\mathrm{BH}$ is an extension of Bore Hole. The soil samples were then analyzed to find out the profile of the soil mechanics at the Soil Mechanics Laboratory, Faculty of Engineering, University of Lampung. Soil mechanical parameters tested in the Laboratory include:

- Water content $(\%)$

- Density $\left(\mathrm{gr} / \mathrm{cm}^{3}\right)$

- Specific Gravity (Gs)

- Passed Sieve No. $200(\%)$

- Atterberg limit tests

$>$ Liquid Limits (LL) $(\%)$

$>$ Plastic Limits (PL) (\%) 
Plasticity Index (PI) (\%)

- Consolidation tests

$>\mathrm{CV}\left(\mathrm{cm}^{2} / \mathrm{s}\right)$

$>\mathrm{Cc}$

- Triaxial tests

$>$ Cohesion (c) $\left(\mathrm{kg} / \mathrm{cm}^{2}\right)$

$>$ Internal Shifting Angle $(\varphi)\left({ }^{\circ}\right)$

$>$ Free Compressive Strength Test $\left(\mathrm{kg} / \mathrm{cm}^{2}\right)$

\subsection{The Analysis of Slope Stability}

An open ground surface that stands at a certain angle to the horizontal direction is called a slope without reinforcement. Slopes can occur scientifically or man-made. If the ground is not horizontal, a component of gravity will tend to move the ground down. If the gravity component is large enough, a slope failure will occur, that is, when the mass of the landslides down. The launching force affects the resistance of shear strength along the surface of the collapse. Civil engineers are often asked to make calculations to check the safety of natural slopes, excavated slopes, and embankment slopes. This check includes determining the shear strength that builds along the surface of the collapse and differentiating it from the shear strength of the soil. This process is called slope stability analysis. In determining the stability or instability of a slope, the term safety factor $(F)$ is introduced. The value is a comparison between the forces that resist the movement and the forces that move the ground. Interpretations of the value of safety factor are [2]:

- $\mathrm{F}>1.0$ : the slope is stable

- $\mathrm{F}=1.0$ : the slope is balanced, and ready for landslides

- $\mathrm{F}<1.0$ : slope is not stable

In this research, the analysis of slope stability is conducted based on the philosophy of Fellenius method, Bowles method, and Janbu method. All the works of stability analysis is undertaken using built-in computer programming called Geostudio slope/w 2012.

\subsection{Fellenius Method [3]}

This method is also called ordinary method of slice. The assumptions used in this method are:

- Field of landslides in a circle

- The landslide field is divided into several upright slices

- The width of each slice does not have to be the same

- More suitable for soil that has values of $\mathrm{c}$ and $\phi$
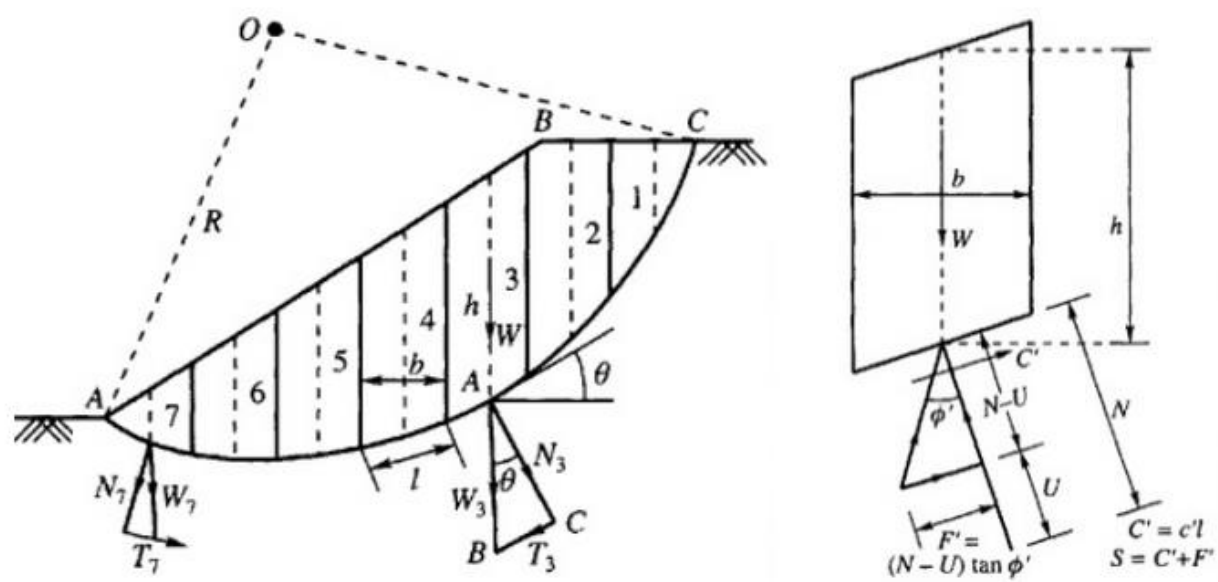

Figure 2. Forces acting on landslides for Fellenius slope analysis method 
This simple method of slices assumes only the overall moment equation of equilibrium written with respect to the center of the slip surface. The shear and normal forces between blocks $X_{i}$ and $E_{i}$ are neglected. Then SF is calculated directly from the following expression:

$$
F S=\frac{1}{\sum_{i} W_{i} \sin \alpha_{i}} \sum_{i}\left(c_{i} l_{i}+\left(N_{i}-u_{i} l_{i}\right) \tan \varphi_{i}\right)
$$

where:

$u_{i}=$ pore pressure within block $i$

$c_{i}, \varphi_{i}=$ effective values of soil parameters

$W i=$ block weight

$N_{i}=$ normal force on the segment of the slip surface

$\alpha_{i}=$ inclination of the segment of the slip surface

$l_{i}=$ length of the segment of the slip surface

\subsection{Bishop Method [4]}

The Bishop method is a very popular method in slope stability analysis due to its simple and fast calculation. This method also provides a fairly thorough calculation of the safety factor. The Bishop method calculates the force components (horizontal and vertical) by considering the moment balance of each piece. This method assumes zero $X i$ forces between blocks. The method is based on satisfying the moment equation of equilibrium and the vertical force equation of equilibrium. The FS is found calculate a consecutive iteration as follows:

$$
F S=\frac{1}{\sum_{i} W_{i} \sin \alpha_{i}} \sum_{i} \frac{c_{i} b_{i}+\left(W_{i-} u_{i} b_{i}\right) \tan \varphi_{i}}{\cos \alpha_{i}+\left[\tan \varphi_{i} \sin \alpha_{i}\right] / F S}
$$

where:
$u_{i}=$ pore pressure within block $i$
$c_{i}, \varphi_{i}=$ effective values of soil parameters
$W i=$ block weight
$N_{i}=$ normal force on the segment of the slip surface
$\alpha_{i}=$ inclination of the segment of the slip surface
$l_{i}=$ length of the segment of the slip surface
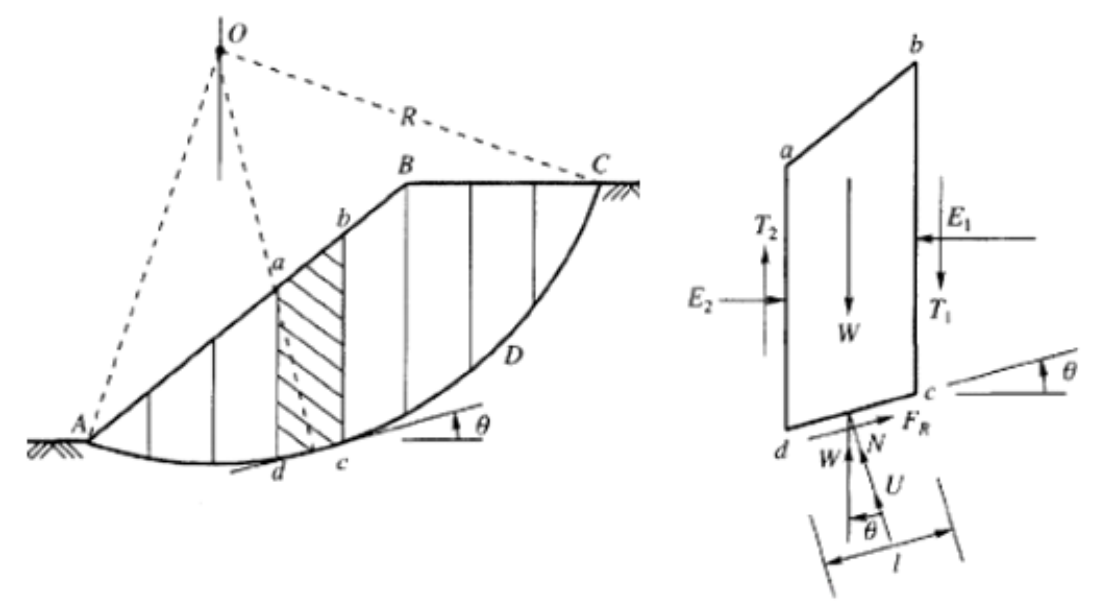

Figure 3. Forces acting on landslides for Bishop slope analysis method 


\subsection{Janbu Method [5]}

Janbu is a soil slice method developed based on boundary balance. It takes a balance of power and satisfying moments that work on a particular block plane. Sliced soil is made by dividing the soil on the slip surface as a plane. The forces acting on each slice can be seen in the following figure:

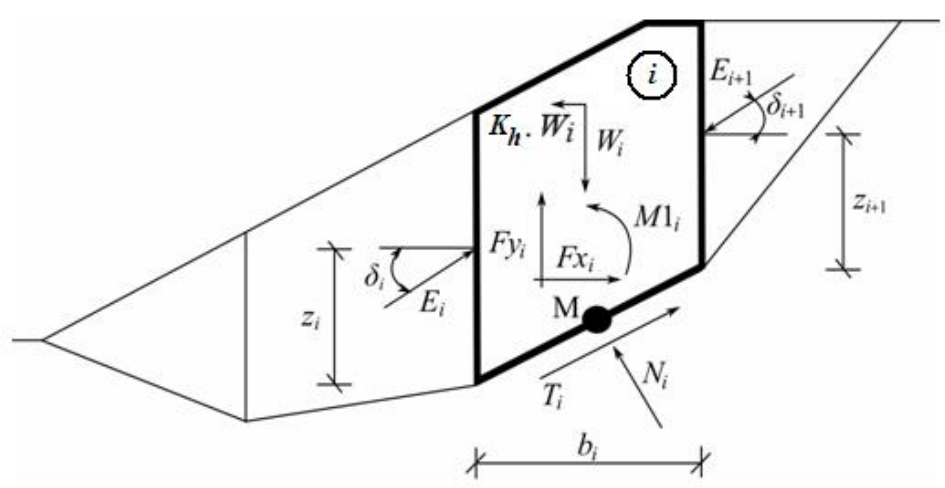

Figure 4. Forces acting on landslides for Janbu slope analysis method

Each slice block is assumed to contribute due to the following forces:

$W_{i}=$ block weight, including material surcharge having the character of weight including the influence of the coefficient of vertical earthquake $K_{v}$

$K_{h} W_{i}=$ horizontal inertia force representing the effect of earthquake, $K_{h}$ is the factor of horizontal acceleration during earthquake

$N_{i} \quad=\quad$ normal force on the slip surface

$T_{i} \quad=$ shear force on the slip surface

$E_{i}, E_{i+1}=$ forces exerted by neighboring blocks, they are inclined from horizontal plane by angle $\delta i$ resp. $\delta_{i+1}$ and lie at the height $z_{i}$ resp. $z_{i+1}$ above slip surface

$F x_{i}, F y_{i}=$ other horizontal and vertical forces acting on block

$M 1_{i} \quad=$ moment from forces $F x_{i}, F y_{i}$ rotating about point M, which is the center of the ith segment of slip surface

$U_{i} \quad=\quad$ pore pressure resultant on the $i_{\text {th }}$ segment of slip surface

The Janbu method takes several assumptions to calculate the balance of force and moment limits on individual blocks:

- The divider between the blocks is always vertical

- $\quad$ The $W_{i}$ block weight action line passes through the center of the slip surface segment which is represented by point $\mathrm{M}$

- $\quad$ The normal force $N_{i}$ works in the middle of the slip surface segment, at point $\mathrm{M}$

- The position of $z_{i}$ force $E_{i}$ acting between blocks is assumed, at the end point of the slip surface is $z=0$

The determination of safety factor value is determined by employing the following iteration process:

- The initial value of angles are set to zero $\delta_{\mathrm{i}}=0$ and positions $\mathrm{z}_{\mathrm{i}}$ to approximately one third of interface height

- The safety factor for a given value of $\delta_{\mathrm{i}}$ follows from equation (5), while assuming the value of $E_{n+1}=0$ at the end of the slip surface

$$
A=\frac{\left[\left(W_{i}-F y_{i}\right) \cos \alpha_{1}-\left(K_{h} W_{i}-F_{x}\right) \sin \alpha_{i}-U_{i}+E_{i} \sin \left(\alpha_{i}-\delta_{i}\right)\right] \frac{\tan \varphi_{i}}{F S}}{\sin \left(\alpha_{i}-\delta_{i+1}\right) \frac{\tan \varphi_{i}}{F S}+\cos \left(\alpha_{i}-\delta_{i+1}\right)}
$$




$$
\begin{gathered}
B=\frac{\left.\frac{c_{i}}{F S} \frac{b_{i}}{\cos \alpha_{1}}-\left(W_{i}-F y_{i}\right) \sin \alpha_{1}-\left(K_{h} W_{i}-F_{x}\right) \cos \alpha_{i}-U_{i}+E_{i} \cos \left(\alpha_{i}-\delta_{i}\right)\right]}{\sin \left(\alpha_{i}-\delta_{i+1}\right) \frac{\tan \varphi_{i}}{F S}+\cos \left(\alpha_{i}-\delta_{i+1}\right)} \\
E_{i+1}=A+B
\end{gathered}
$$

- The value of $\delta_{\mathrm{i}}$ is provided by equation (5) using the values of $\mathrm{E}_{\mathrm{i}}$ determined in the previous step.

- The steps are then repeated until the value of FS does not change.

Unstable solutions have to be avoided for successful iteration process. Such instabilities occur at points where the equation is division by zero, for example:

$$
F S=\tan \alpha_{1} \tan \left(\delta_{i+1}-\alpha_{i}\right)
$$

Another check to avoid numerical instability is the verification of parameter $\mathrm{m}_{\alpha}$ :

$$
m_{\alpha}=\cos \alpha_{1} \frac{\sin \alpha_{1} \tan \varphi_{i}}{F S}>0,2
$$

\subsection{GeoStudio}

GeoStudio is integrated software products for geotechnical modeling \& analysis. This software has been developed in Canada since 1977. GeoStudio has the ability to overcome planning problems related to strengthening soil structure such as deformation analysis and soil stability. In the analysis, the properties of structural components can be included in the stress deformation analysis so that the forces and moments in the structure can be calculated together with the interaction between the structure and the soil. Stability analysis can also be carried out with all or part of structural load components that are assumed to be applied to the shear mass. Structural components can be used or ignored to simulate actual field conditions.

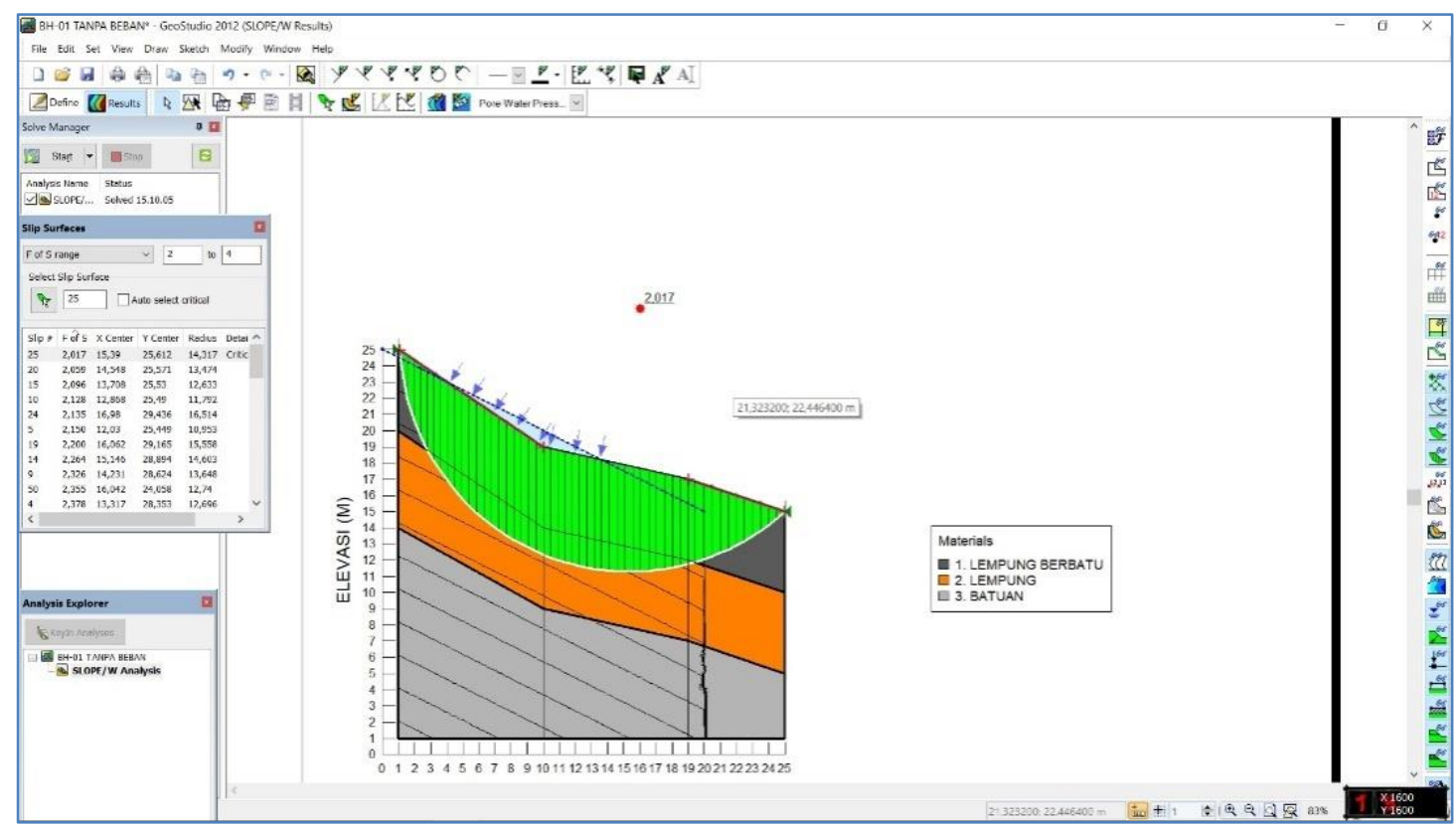

Figure 4. Graphical User Interface (GUI) of GeoStudio (Slope/W) software 
Slope/W is a component that is part of GeoStudio. The conventional Limit Equilibrium method is the basis for calculating slope stability analysis in the GeoStudio (Slope/W) Program. The Limit Equilibrium method is formulated in the form of moments and calculates the value of the safety factor from the moment equation balance. In this analysis, the safety factor is defined as the ratio of the shear resistance available to the one that needed for balance condition. The analysis of slope stability in this research uses Fellenius, Bishop, and Janbu in the Geostudio (Slope/W) software.

\section{Results and discussions}

Soil samples taken from the field are then brought to the laboratory to investigate the characteristics of soil mechanics through several tests. The results of the test are presented in the following table:

Table 1. The characteristics of soil mechanics of the samples

\begin{tabular}{lccccccc}
\hline $\begin{array}{l}\text { Bore } \\
\text { Hole }\end{array}$ & Depth & $\begin{array}{c}\text { Water } \\
\text { content } \\
(\%)\end{array}$ & $\begin{array}{c}\text { Density } \\
\left(\mathrm{gr} / \mathrm{cm}^{3}\right)\end{array}$ & $\begin{array}{c}\text { Specific } \\
\text { Gravity } \\
(\mathrm{Gs})\end{array}$ & $\begin{array}{c}\text { Passed } \\
\text { Sieve No. } \\
200(\%)\end{array}$ & $\begin{array}{c}\text { Liquid } \\
\text { Limits } \\
(\mathrm{LL})(\%)\end{array}$ & $\begin{array}{c}\text { Plastic } \\
\text { Limits } \\
(\mathrm{PL})(\%)\end{array}$ \\
\hline BH-01 & $-5 \mathrm{~m}$ & 43,53 & 1,465 & 2,471 & 68,65 & 65,17 & 46,39 \\
& $-10 \mathrm{~m}$ & 63,46 & 1,435 & 2,569 & 62,95 & 65,81 & 53,21 \\
\hline BH-02 & $-5 \mathrm{~m}$ & 53,24 & 1,478 & 2,515 & 31,64 & 64,86 & 45,94 \\
\hline BH-03 & $-5 \mathrm{~m}$ & 56,7 & 1,428 & 2,565 & 19,21 & 96,71 & 61,38 \\
\hline BH-04 & $-5 \mathrm{~m}$ & 60,91 & 1,415 & 2,586 & 28,4 & 62,71 & 38,07 \\
& $-15 \mathrm{~m}$ & 45,55 & 1,547 & 2,529 & 35,8 & 56,02 & 32,16 \\
\hline BH-05 & $-5 \mathrm{~m}$ & 74,62 & 1,469 & 2,585 & 61,02 & 106,79 & 68,83 \\
& $-10 \mathrm{~m}$ & 42,33 & 1,421 & 2,522 & 46,02 & 81,72 & 56,35 \\
& $-15 \mathrm{~m}$ & 32,62 & 1,527 & 2,5 & 70,05 & 59,88 & 35,26 \\
\hline
\end{tabular}

Table 2. The characteristics of soil mechanics of the samples (cont.)

\begin{tabular}{cccccccc}
\hline $\begin{array}{l}\text { Bore } \\
\text { Hole }\end{array}$ & Depth & $\begin{array}{c}\text { Plasticity } \\
\text { Index } \\
(\mathrm{PI})(\%)\end{array}$ & $\begin{array}{c}\mathrm{CV} \\
\left(\mathrm{cm}^{2} / \mathrm{s}\right)\end{array}$ & $\mathrm{Cc}$ & $\begin{array}{c}\text { Cohesion } \\
(\mathrm{c}) \\
\left(\mathrm{kg} / \mathrm{cm}^{2}\right)\end{array}$ & $\begin{array}{c}\text { Internal } \\
\text { Shifting } \\
\text { Angle }(\varphi)(\mathrm{o})\end{array}$ & $\begin{array}{c}\text { Free Comp. } \\
\text { Strength Test } \\
\left(\mathrm{kg} / \mathrm{cm}^{2}\right)\end{array}$ \\
\hline BH-01 & $-5 \mathrm{~m}$ & 18,78 & 0,07 & 0,204 & 0,13 & 11,8 & 0,4 \\
& $-10 \mathrm{~m}$ & 12,6 & 0,057 & 0,234 & 0,103 & 13,4 & 0,38 \\
\hline BH-02 & $-5 \mathrm{~m}$ & 18,93 & 0,148 & 0,238 & 0,185 & 15,9 & 0,07 \\
\hline BH-03 & $-5 \mathrm{~m}$ & 35,33 & 0,072 & 0,239 & 0,099 & 15,4 & 0,39 \\
\hline BH-04 & $-5 \mathrm{~m}$ & 24,64 & 0,068 & 0,258 & 0,033 & 14,4 & 0,13 \\
& $-15 \mathrm{~m}$ & 23,86 & 0,108 & 0,2 & 0,092 & 13,5 & 0,25 \\
\hline BH-05 & $-5 \mathrm{~m}$ & 37,96 & 0,083 & 0,301 & 0,05 & 20,7 & 0,36 \\
& $-10 \mathrm{~m}$ & 25,37 & 0,094 & 0,234 & 0,121 & 20,5 & 0,47 \\
& $-15 \mathrm{~m}$ & 24,62 & 0,089 & 0,213 & 0,184 & 19,4 & 0,53 \\
\hline
\end{tabular}

Then, using Geostudio software, all samples from each location were analyzed with the final goal of finding the value of the slope safety factor of each location based on calculations from the Fellenius method, the Bishop method, and the Janbu method. The results are: 
Table 3. Safety factor value for each bore hole based on calculations using the Fellenius method, the Bishop method, and the Janbu method

\begin{tabular}{|c|c|c|c|c|}
\hline \multirow{2}{*}{ Bore hole } & \multirow{2}{*}{ Load variation } & \multicolumn{3}{|c|}{ Safety factor value } \\
\hline & & Fellenius method & Bishop method & Janbu method \\
\hline \multirow{5}{*}{ ВН-01 } & 0 Ton & 2.017 & 2.185 & 2.020 \\
\hline & 5 Tons & 2.064 & 2.190 & 1.965 \\
\hline & 10 Tons & 2.020 & 2.189 & 1.964 \\
\hline & 15 Tons & 2.021 & 2.190 & 1.965 \\
\hline & 20 Tons & 2.020 & 2.190 & 1.965 \\
\hline \multirow{5}{*}{ BH-02 } & 0 Ton & 3.987 & 4.357 & 4.168 \\
\hline & 5 Tons & 3.524 & 3.458 & 3.443 \\
\hline & 10 Tons & 2.599 & 3.335 & 1.857 \\
\hline & 15 Tons & 2.310 & 2.326 & 1.711 \\
\hline & 20 Tons & 2.245 & 2.015 & 2.056 \\
\hline \multirow{5}{*}{ BH-03 } & 0 Ton & 3.711 & 3.873 & 3.702 \\
\hline & 5 Tons & 3.711 & 3.581 & 3.412 \\
\hline & 10 Tons & 3.418 & 3.579 & 3.411 \\
\hline & 15 Tons & 3.418 & 3.579 & 3.411 \\
\hline & 20 Tons & 3.259 & 3.419 & 3.251 \\
\hline \multirow{5}{*}{ BH-04 } & 0 Ton & 2.028 & 2.093 & 2.386 \\
\hline & 5 Tons & 2.028 & 2.093 & 2.386 \\
\hline & 10 Tons & 2.000 & 2.035 & 2.007 \\
\hline & 15 Tons & 1.986 & 2.035 & 2.040 \\
\hline & 20 Tons & 1.947 & 1.862 & 1.749 \\
\hline \multirow{5}{*}{ BH-05 } & 0 Ton & 2.126 & 2.232 & 2.034 \\
\hline & 5 Tons & 2.256 & 2.318 & 2.096 \\
\hline & 10 Tons & 1.948 & 2.042 & 1.936 \\
\hline & 15 Tons & 1.804 & 2.006 & 1.811 \\
\hline & 20 Tons & 1.822 & 1.882 & 1.748 \\
\hline
\end{tabular}

The table shows that the safety factors for slope stability at the study locations are always $>1$, which means that all the land at the location that is reviewed is safe from landslides. Physically, it is known that the type of soil in the study area is soil that has layers that have moderate to good quality. In addition, the slopes reviewed are not too steep so the soil tends to be stable from landslides. The highest safety number value is achieved when the load $=0$. Load variations are added to the soil model analyzed by adding a load with a multiple of 5 tons. The calculation results also show that there is a decrease in the value of the safety factor along with the increase in burden. However, the decrease is not significant when compared to the value before being given a burden. This shows that the physical properties of the soil are quite uniform from the surface to a certain depth. The difference in computation among the Fellenius method, the Bishop method, and the Janbu method does not produce too different safety factor values. This shows that all three models have the same accuracy in estimating landslide hazards. Such statements are supported by several previous studies. Research comparing the results of the calculation of the three methods with the results of the calculation of finite difference numerical method (FDM) shows a very close relationship between these results [6].

However, until now there has been no expert who states that one method is better than another method. One expert stated that each model has its own specificity in its use. For example, the Bishop method is only good when used to analyze circular slip surfaces. On the other hand, Janbu's method is best when used to analyze shallow and elongated slip surfaces and the Fellenius method is good when used to analyze any type of slip surface. Some others said that the However, most experts argue that the greatness of a method in analyzing slope slides depends on the type of slope and soil under investigation. 


\section{Conclussions}

Slope stability analysis in Ulubelu Lampung for geothermal pipeline network development has been analyzed. Three method of slope stability analysis: Fellenius method, Bishop method, and Janbu method have been used to calculate safety factor of each sampling location. The calculation is undertaken using GeoStudio (Slope/W) Program. The characteristics of soil mechanics at the five studied locations indicate similarity. Therefore, the values of the safety factors that are produced are also not much different from each other. The results also showed that the value of the safety factor produced was 1.8 to 4.3 which showed that all the land in all locations studied had sufficient security against landslides. However, from the three methods used to calculate the safety factor in this study, it can be concluded that the accuracy of each model is not much different. According to experts the superiority of a method in analyzing slope slides depends on the type of slope and the soil under investigation.

\section{Acknowledgements}

The authors wish to convey their deep gratitude and appreciation to the Civil Engineering Department, University of Lampung for their support in this research. The authors also wish to thank to Dr. Gatot Susilo who has assisted them in writing this paper.

\section{References}

[1] Margrit, Annisa, 2001. Pembangkit listrik panas bumi: Berkah Ulubelu bagi masyarakat (in Bahasa Indonesia). Website: https://banten.bisnis.com/read/20170620/451/664240/ pembangkit-listrik-panas-bumi-berkah-ulubelu-bagi-masyarakat [Acessed Feb 28, 2020].

[2] Pangemanan M. G. V., Turangan A.E and Sompie O.B.A., 2014. Analisis kestabilan lereng dengan metode Fellenius (Studi kasus: Kawasan Citraland). Jurnal Sipil Statik, Vol.2(1), pp. $37-46$.

[3] Petterson K. E., 1955. The early history of circular sliding surfaces. Geotechnique, Vol(5), pp. 275-296.

[4] Bishop, A.W., 1955. The Use of the Slip Circle in the Stability Analysis of Slopes. Geotechnique, Vol. 5(1), pp. 7-17.

[5] Janbu, N. 1973. Slope Stability Computations. Embankment Dam Engineering - Casagrande Volume, R.C. Hirschfeld and S.J. Poulos, eds., John Wiley and Sons, New York, pp 47-86.

[6] Mansour, Z. S. and Kalantari, B. 2011. Traditional Methods vs. Finite Difference Method for Computing Safety Factors of Slope Stability. Electronic Journal of Geotechnical Engineering, No. 16, pp. $1119-1130$. 